\title{
Production Efficiency of Promising Mungbean Genotypes Affected by Different Sowing Dates Under Rainfed Conditions
}

\author{
Muhammad Aqeel Sarwar*1, Shahid Riaz Malik', Waqas Ahmad², Muhammad Sajid Mahmood', \\ Muhammad Jawad ${ }^{1}$, Muhammad Asadullah ${ }^{1}$, Ijaz Ahmad $^{4}$ and Muhammad Imran ${ }^{1}$
}

${ }^{1}$ Crop Sciences Institute, National Agricultural Research Centre, Islamabad, Pakistan; ${ }^{2}$ College of Agriculture, Bahauddin Zakariya University, Bahadur Sub-campus, Layyah, Pakistan; ${ }^{3}$ PMAS-Arid Agriculture University Rawalpindi, Pakistan; ${ }^{4}$ Ecotoxicology Research Institute, NARC, Islamabad, Pakistan.

\begin{abstract}
Determination of optimum sowing time for mungbean is inevitable which may vary from variety to variety due to variation in agroecological conditions. Therefore a field trial was conducted at pulses research field NARC, Islamabad, to establish the optimum sowing time and suitable genotype for rainfed conditions of the area. The treatments were five sowing dates (15 June, 25 June, 05 July, 15 July and 25 July) and two promising genotypes (NM-11, NCM-2013). Experiment was laid out in randomized complete block design (RCBD) with split plot arrangement by using three replications. Data regarding growth, yield attributes and yield were collected and analyzed. Considering the individual effect, results depicted that among genotypes $\mathrm{G}_{2}$ (NCM-13) exhibited significantly better performance as compared to $\mathrm{G}_{1}$ (NM-11) for most of the studied traits including yield. In case of planting times delayed sowing enhanced the maturity but July 05 reported best results especially for yield attributes like no. of clusters per plant, pods plant ${ }^{-1}$, biological yield, grain yield and harvest index, however it was statistically similar with planting time July 15 for all these traits. The interaction also exhibited significant results and $\mathrm{G}_{2} \mathrm{~S}_{3}$ recorded highest yield than all other treatments. So, it can be concluded that genotype NCM-13 should be grown from 05 July to 15 July for maximizing the mungbean yield under rainfed conditions of the area.

Received | February 26, 2018; Accepted | May 24, 2018; Published | December 13, 2018

*Correspondence | Muhammad Aqeel Sarwar, Crop Sciences Institute, National Agricultural Research Centre, Islamabad, Pakistan; Email: maqeeluaf@gmail.com

Citation | Sarwar, M.A., S.R. Malik, W. Ahmad, M.S. Mahmood, M. Jawad, M. Asadullah, I. Ahmad and M. Imran. 2019. Production efficiency of promising mungbean genotypes affected by different sowing dates under rainfed conditions. Pakistan Journal of Agricultural Research, 32(1): 52-58.

DOI | http://dx.doi.org/10.17582/journal.pjar/2019/32.1.52.58

Keywords | Genotypes, Sowing date, Growth, Yield, Mungbean
\end{abstract}

\section{Introduction}

$\mathrm{T}$ here is an appalling increase in world population and obviously this overpopulated world is clearly overwhelmed by inadequate and unbalanced diet. Plant scientists are facing the challenge of meeting the food needs of this uncontrolled population (Thirtle et al., 2003). In this sensitive context, pulses are the best choice for dietary protein, when consumed with other cereals they certainly meet the requirements of a balanced diet. Mungbean (Vigna radiata L.) generally known as green gram is an important pulse crop in many Asian countries including Pakistan which contains high quality vegetable protein and satisfactory amounts of minerals and vitamins. It is mostly consumed by humans and also used for fodder purpose. Its seed consists of $24.3 \%$ protein and $0.67 \%$ fats (Lee et al., 1997) and being leguminous in nature, 
it also maintains soil fertility by symbiotically fixing nitrogen in the atmosphere with strains of Rhizobia and annually can fix $300 \mathrm{~kg} \mathrm{ha}^{-1}$ of atmospheric nitrogen (Sharar et al., 2001).

Despite its importance for food and feed, the attention towards its qualitative and quantitative improvement has received less attention throughout the country. It is the second most grown pulse after chickpea (Cicer arietinum L.) with total area under cultivation 178000 ha and with 130000 tonnes production with an average yield of $730 \mathrm{~kg} \mathrm{ha}^{-1}$ (GOP, 2016-17) which is lower than the potential yield of existing varieties $\left(1.5\right.$ tons ha $\left.{ }^{-1}\right)$. Different factors that cause low yields of mungbean in the field are: un-awareness of farmers about optimum date of sowing, inappropriate varieties and planting patterns, lack of plant protection measures and improper use of fertilizers. Of these factors, use of appropriate varieties and optimum sowing time are very important. A good number of high yielding mungbean varieties are available now and for any yield improvement programme selection of superior varieties is a prerequisite for specific ecological conditions (Khan et al., 2001; Ahmad et al., 2008). Sowing time, a non-monetary input, is the single most important factor to obtain optimum yield from mungbean (Samanta et al., 1999). Early sowing can cause excessive vegetative growth with high pests and diseases infestation and rain damage during maturity period, while late sowing may result in lower grain yield due to shorter growing season and ultimately decreased photosynthates accumulation (Taleei et al., 1999; Malik et al., 2006). So, determination of optimum sowing time for mungbean is inevitable which may vary from variety to variety and season to season due to variation in agroecological conditions. The overall scenario and background clearly reflect the need for due attention to these parameters, which may threaten the management practices to reduce yields per unit area. Therefore, the purpose of this study was to determine the production efficiency of promising mungbean genotypes with different sowing dates. This agronomic information will help to improve mungbean productivity, especially in the rainfed conditions of Pothowar, Pakistan.

\section{Materials and Methods}

The experiment was conducted at pulses research field, CSI at NARC in Islamabad during Kharif 2017. The climate of the region is sub humid and subtropical.
The experimental area is located at $33.43^{\circ}$ North latitude and $73.04^{\circ}$ East longitude with an altitude of $540 \mathrm{~m}$ on the globe.

There were five sowing dates (15 June, 25 June, 05 July, 15 July and 25 July) and two promising mungbean genotypes (NM-11, NCM-2013). The experiment was laid out in randomized complete block design with split plot arrangement and three replications. Ten treatments were allocated in each replication at random with sowing dates in main plots and genotypes in sub plots, while row-row spacing was kept $30 \mathrm{~cm}$ and row length was kept $4 \mathrm{~m}$ with the plot size of $4.8 \mathrm{~m}^{2}$. Sowing was done with single row hand drill and all other agronomic practices were kept normal and uniform for all treatments. Meteorological data regarding average temperature $\left({ }^{\circ} \mathrm{C}\right)$, rainfall $(\mathrm{mm})$ and relative humidity (\%) were recorded from meteorological observatory in the immediate locality of the field during the phase of crop development (Figure 1). Data on plant height, no of pods per plant, pod length, seeds per pod, seed yield, biological yield, harvest index, days to $50 \%$ flowering and maturity times were recorded during the course of study. For recording data the plant population per plot was counted and then converted to $\mathrm{m}^{-2}$. Days to $50 \%$ flowering were recorded by counting the days from date of sowing to the date when flowers appeared on $50 \%$ plants. Similarly, days to maturity were recorded by counting the number of days from sowing to about $90 \%$ physiological maturity of crop. For plant height five randomly selected plants from each plot were measured with the help of measuring rod and then average was recorded and from the same five plants the No. of clusters and pods for each plant were counted separately and then averaged. Ten filled pods from five different plants were harvested and their length were recorded with the help of measuring rod and averaged. From the same pods number of seeds pod ${ }^{-1}$ were counted and averaged. Rows of each plot were harvested with the help of a sickle, sun dried and biological yield for each experimental unit $(4 \mathrm{~m} \times 1.2 \mathrm{~m})$ was noted and converted into $\mathrm{kg} \mathrm{ha} \mathrm{h}^{-1}$ and after threshing grain yield in $\mathrm{kg}$ plot $^{-1}$ was calculated then it was converted into $\mathrm{kg} \mathrm{ha}^{-1}$ while harvest index (\%) was calculated by using the following formula:

\section{Harvest Index $=\frac{\text { Grain Yield }}{\text { Biological Yield }} \times 100$}

The data recorded for different parameters were sub- 
jected for the analysis of variance to determine the significance of differences between treatments. Least significant difference of the mean was also calculated at $5 \%$ probability level using Statistix 8.1 software package. (Steel et al., 1997).

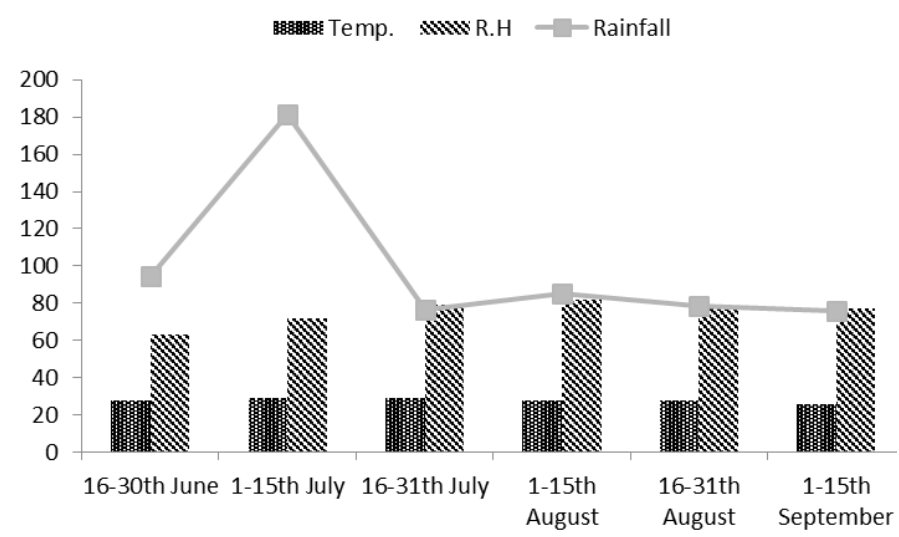

Figure 1: Meteorological data showing mean fortnightly temperature, humidity and rainfall during growing seasons of mungbean.

\section{Results and Discussion}

\section{Plant population $m^{-2}$}

The results presented for plant population $\mathrm{m}^{-2}$ (Table 1) were significantly different for mungbean genotypes. Higher plant population (61.33) was recorded in genotype NCM-13 while plant population was found to be low in NM-11 (52.06). Sowing dates was also found significant in case of plant population. Highest (68.16) plant population was noted when plots were sown on July 25 followed by July 15 and July $5(67.66,51.66)$ respectively, though there was no statistical difference among these three. However statistically lowest plant population $\mathrm{m}^{-2}$ (44.66) was observed in case of early sowing June 15 . The interaction $\mathrm{G} \times \mathrm{S}$ was also significant where maximum plant population (77) was observed for the interaction $G_{2} \times S_{5}$. These results are in confirmation with the findings of Steele and Grabau (1997), who reported that early sowing leads to low plant population. Similar results were also reported by Fraz et al., 2006.

\section{Plant height $(\mathrm{cm})$}

Statistical analysis of the data (Table 1) revealed that genotypes and planting dates significantly affected the plant height of mungbean. Plots sown with genotype NCM-13 produced plants with significantly greater plant height $(68.16 \mathrm{~cm})$ compared to the plots sown with NM-11. In case of planting times the plots planted on July 15 reported maximum plant height $(70.45 \mathrm{~cm})$ which was statistically at par with 68.00 , 65.11 and $60.50 \mathrm{~cm}$ height when plots were sown on
July 5, June 25 and July 25 respectively. While minimum plant height $(56.70 \mathrm{~cm})$ was observed in case of early sowing, done on June 15 . The interaction was also significant by measuring maximum plant height $(73.78 \mathrm{~cm})$ with $\mathrm{G}_{2} \times \mathrm{S}_{4}$. The differences among the varieties might be due to their genetic constituents Miah et al., 2009. Plant height increased gradually with delay in sowing due to increased temperature as reported by Poehlman (1993).

Table 1: Plant population $\mathrm{m}^{-2}$, Plant height (cm), Days to 50\% flowering and Days to maturity of mungbean genotypes as affected by different sowing dates.

\begin{tabular}{|c|c|c|c|c|}
\hline Treatments & $\begin{array}{l}\text { Plant } \\
\text { Popula- } \\
\text { tion } \text { m }^{-2}\end{array}$ & $\begin{array}{l}\text { Plant } \\
\text { Height } \\
\text { (cm) }\end{array}$ & $\begin{array}{l}\text { Days to } \\
50 \% \text { Flow- } \\
\text { ering }\end{array}$ & $\begin{array}{l}\text { Days to } \\
\text { Matu- } \\
\text { rity }\end{array}$ \\
\hline \multicolumn{5}{|l|}{ Genotypes } \\
\hline $\mathrm{G}_{1}=\mathrm{NM}-11$ & $52.06 \mathrm{~b}$ & $60.13 \mathrm{~b}$ & 39 & 84.4 \\
\hline $\mathrm{G}_{2}=\mathrm{NCM} 13$ & $61.33 \mathrm{a}$ & $68.16 \mathrm{a}$ & 39 & 88.2 \\
\hline $\operatorname{LSD}(p=0.05)$ & 6.79 & 6.64 & NS & NS \\
\hline \multicolumn{5}{|l|}{ Sowing dates } \\
\hline $\mathrm{S}_{1}=$ June 15 & $44.66 \mathrm{c}$ & $56.70 \mathrm{~b}$ & $43 \mathrm{a}$ & $91.0 \mathrm{a}$ \\
\hline $\mathrm{S}_{2}=$ June 25 & $51.33 \mathrm{bc}$ & $65.11 \mathrm{ab}$ & $41 \mathrm{~b}$ & $89.0 \mathrm{ab}$ \\
\hline $\mathrm{S}_{3}=$ July 5 & $51.66 \mathrm{abc}$ & $68.00 \mathrm{ab}$ & $37 \mathrm{c}$ & $86.5 \mathrm{bc}$ \\
\hline $\mathrm{S}_{4}=$ July 15 & $67.66 \mathrm{ab}$ & $70.45 \mathrm{a}$ & $37 \mathrm{c}$ & $83.5 \mathrm{~cd}$ \\
\hline $\mathrm{S}_{5}=$ July 25 & $68.16 \mathrm{a}$ & $60.50 \mathrm{ab}$ & $37 c$ & $80.5 \mathrm{~d}$ \\
\hline $\operatorname{LSD}(p=0.05)$ & 16.58 & 10.07 & 1.20 & 3.2 \\
\hline \multicolumn{5}{|l|}{ Interaction $S^{*} G$} \\
\hline $\mathrm{G}_{1} \times \mathrm{S}_{1}$ & $40 \mathrm{e}$ & $53.56 \mathrm{~d}$ & $42.67 \mathrm{ab}$ & $90 \mathrm{ab}$ \\
\hline $\mathrm{G}_{1} \times \mathrm{S}_{2}$ & 50 cde & $59.11 \mathrm{bcd}$ & $40.67 c$ & $89 \mathrm{abc}$ \\
\hline $\mathrm{G}_{1} \times \mathrm{S}_{3}$ & $47 \mathrm{de}$ & $65.44 \mathrm{abcd}$ & $37.00 \mathrm{de}$ & $85 \mathrm{~cd}$ \\
\hline $\mathrm{G}_{1} \times \mathrm{S}_{4}$ & $64 \mathrm{abc}$ & $67.11 \mathrm{abc}$ & $37.33 \mathrm{~d}$ & 80 ef \\
\hline $\mathrm{G}_{1} \times \mathrm{S}_{5}$ & $60 \mathrm{bcd}$ & $55.44 \mathrm{~cd}$ & $37.33 \mathrm{de}$ & $78 \mathrm{f}$ \\
\hline $\mathrm{G}_{2} \times \mathrm{S}_{1}$ & 49 cde & $59.83 \mathrm{bcd}$ & $43.00 \mathrm{a}$ & $93 \mathrm{a}$ \\
\hline $\mathrm{G}_{2} \times \mathrm{S}_{2}$ & 53 cde & $71.11 \mathrm{ab}$ & $41.33 b c$ & $90 \mathrm{ab}$ \\
\hline $\mathrm{G}_{2} \times \mathrm{S}_{3}$ & $56 \mathrm{bcd}$ & $70.56 \mathrm{ab}$ & $37.00 \mathrm{de}$ & $88 \mathrm{bc}$ \\
\hline $\mathrm{G}_{2} \times \mathrm{S}_{4}$ & $71 \mathrm{ab}$ & $73.78 \mathrm{a}$ & $36.33 \mathrm{e}$ & $87 \mathrm{bcd}$ \\
\hline $\mathrm{G}_{2} \times \mathrm{S}_{5}$ & $77 \mathrm{a}$ & $65.56 \mathrm{abcd}$ & 37.33de & $83 \mathrm{de}$ \\
\hline $\operatorname{LSD}(p=0.05)$ & 15 & 12.2 & 0.93 & 4.6 \\
\hline
\end{tabular}

\section{Days to $50 \%$ flowering}

Days to $50 \%$ flowering was found non-significant for mungbean genotypes (Table 1). While sowing dates had a significant effect on days to $50 \%$ flowering of mungbean. Maximum days to 50\% flowering (43) was recorded when mungbean was planted on June 15 followed by 41 days in case of crop sown on June 25. Sowing date 3, 4 and 5 (July 5, July 15 and July 25 ) took minimum days to $50 \%$ flowering (37) and 
were found statistically same. $\mathrm{G} \times \mathrm{S}$ interaction also showed significant response where maximum days to $50 \%$ flowering were recorded in case of $\mathrm{G}_{2} \times \mathrm{S}_{1}$. Days to flowering opted to reduce when sowing was done late. These findings contradict with the results of $\mathrm{Re}^{-}$ hman et al., 2009 who indicated that days to $50 \%$ flowering was non-significant for sowing dates (D), varieties $(\mathrm{V})$ and $\mathrm{D} \times \mathrm{V}$ interaction.

\section{Days to maturity}

Similarly, days taken to maturity for genotypes were found non-significant while sowing dates were found significant with maximum days to maturity (91) when crop was sown on June 15 followed by 89 and 86.5 days for June 25 and July 5 sowing respectively. While the minimum days taken to maturity (80.5) were recorded for plots where sowing was accomplished late, on July $25 . \mathrm{G}_{2} \times \mathrm{S}_{1}$ interaction took maximum days to maturity (93). Due to decreasing temperature and soil moisture due to less rains in September and October the cropped switched earlier towards maturity to complete its life cycle which resultantly decreased maturity days and also grain yield. Delayed sowing resulted in a decrease in days to maturity Rehman et al., 2009. These results were found same to those of Yadav et al. (1995) who indicated that late sowing caused a decrease in days to maturity.

\section{Number of clusters plant ${ }^{-1}$}

Number of clusters plant ${ }^{-1}$ of mungbean as affected by genotypes and sowing dates presented in Table 2 showed that genotypes and sowing dates had no significant effect on this parameter though NCM-13 performed better than NM-11 and S3 (July, 05) gave better results than all other sowing dates. However, the interaction significantly affected the number of clusters plant ${ }^{-1}$ with a maximum value of 7.89 in case of $\mathrm{G}_{2} \times \mathrm{S}_{3}$.

\section{Pod length $(\mathrm{cm})$ and number of grains pod ${ }^{-1}$}

The statistical analysis of the data revealed that sowing dates $(S)$, genotypes $(G)$ and $G \times S$ interaction showed non-significant effect (Table 2). Mungbean recorded statistically same pod length for both varieties and all sowing dates. however, NCM-13 performed better than NM-11 and likewise $\mathrm{S}_{4}$ (July 15) gave better results than all other sowing dates. This might be due to the factor that pod length is a genetic trait of the variety and is not affected by planting dates. Similar trend for the data of no. of grains per pod was noted as a result of statistical anlaysis. But the interaction here was noted significant in which $\mathrm{G}_{2} \times \mathrm{S}_{4}$ produced maximum number of grains pod $^{-1}$.

\section{Number of pods plant ${ }^{-1}$}

Genotypes and sowing dates had a significant effect on number of pods plant ${ }^{-1}$ (Table 2). NCM -13 produced highest number of pods plant ${ }^{-1}$ (35.97) while NM-11 yielded lowest pods plant ${ }^{-1}$ (27.22) among the two genotypes. In case of sowing dates, $\mathrm{S}_{3}$ (July $05)$ produced the highest number of pods plant ${ }^{-1}$ followed by sowing date 1, 2 and 4 (June 15, June 25 and July 15) respectively which were found statistically identical with $32.94,32.55$ and 31.55 number of pods plant $^{-1}$ respectively. The interaction $\mathrm{G}_{2} \times \mathrm{S}_{3}$ also produced statistically maximum number of pods plant ${ }^{-1}$ (42.56) as compared to others. This might be due to reason that flowering period was not coincided with heavy rains and temperature was also mild which reduced flower shedding and resultantly improved pod nmbr/ cluster plant. Soomro (2003) reported that delay in sowing causes a substantial decrease in all the growth and development parameters of mungbean. Siddique et al. (2006), Mondal (2004) and Patil et al. (2003) also reported similar results to those obtained in the following study.

\section{Biological yield $\mathrm{kg} \mathrm{ha} \mathrm{ha}^{-1}$}

Biological yield for genotypes, sowing dates and their interaction also showed significant results (Table 2). Higher biological yield (4326) was recorded for plots grown with NCM-13 as compared to $\left(3697 \mathrm{~kg} \mathrm{ha}^{-}\right.$ $\left.{ }^{1}\right)$ when plots were grown with NM-11. For sowing dates, the maximum biological yield $\left(68.16 \mathrm{~kg} \mathrm{ha}^{-1}\right)$ was obtained when plots were sown on July 05 followed by 4381 and 4270 when the sowing was done on June 25 and July 15. While minimum biological yield (3194 kg ha-1) was obtained in case of early sowing, June 15 . The interaction $\mathrm{G} \times \mathrm{S}$ was also found significant. Maximum biological yield $\left(5249 \mathrm{~kg} \mathrm{ha}{ }^{-1}\right)$ was observed for the interaction $\mathrm{G}_{2} \times \mathrm{S}_{3}$. These results contradict to those of Quresh and Rahim (1987), who reported that early sowing produced significantly higher mean biological yield. However, difference in biological yield among mungbean genotypes have also been reported by different other many researchers (Tomar and Tiwari, 1996; Sarkar et al., 2004).

\section{Grain yield $\mathrm{kg} \mathrm{ha}^{-1}$}

Data regarding grain yield of mungbean as affected by genotypes $(G)$ and various sowing dates $(S)$ is present in Table 2. Significant statistical difference among 
Table 2: Yield and yield contributing attributes of mungbean genotypes as affected by different sowing dates.

\begin{tabular}{|c|c|c|c|c|c|c|c|}
\hline Treatments & $\begin{array}{l}\text { No. of Clusters/ } \\
\text { plant }\end{array}$ & $\begin{array}{l}\text { Pod length } \\
\text { (cm) }\end{array}$ & Grains/Pod & $\begin{array}{l}\text { No of Pods/ } \\
\text { Plant }\end{array}$ & $\begin{array}{l}\text { Bio yield kg/ } \\
\text { ha }\end{array}$ & $\begin{array}{l}\text { Grain yield } \\
\mathrm{kg} / \mathrm{ha}\end{array}$ & HI\% \\
\hline \multicolumn{8}{|l|}{ Genotypes } \\
\hline $\mathrm{G}_{1}=\mathrm{NM}-11$ & 5.71 & 8.46 & 10.9 & $27.22 \mathrm{~b}$ & $3697 \mathrm{~b}$ & $544 \mathrm{~b}$ & $14.55 \mathrm{~b}$ \\
\hline $\mathrm{G}_{2}=\mathrm{NCM} 13$ & 6.59 & 8.84 & 11.24 & $35.97 \mathrm{a}$ & $4326 \mathrm{a}$ & $823 \mathrm{a}$ & $18.41 \mathrm{a}$ \\
\hline $\operatorname{LSD}(p=0.05)$ & NS & NS & NS & 5.88 & 426 & 180 & 3.68 \\
\hline \multicolumn{8}{|l|}{ Sowing dates } \\
\hline $\mathrm{S}_{1}=$ June 15 & 5.61 & 8.61 & 10.16 & $32.94 \mathrm{ab}$ & $3194 \mathrm{c}$ & $438 c$ & $12.98 \mathrm{c}$ \\
\hline $\mathrm{S}_{2}=$ June 25 & 6.05 & 8.75 & 10.5 & $32.55 \mathrm{ab}$ & $4381 \mathrm{ab}$ & $721 \mathrm{ab}$ & $15.75 \mathrm{bc}$ \\
\hline $\mathrm{S}_{3}=$ July 5 & 6.83 & 8.61 & 11.44 & $35.77 \mathrm{a}$ & $4638 \mathrm{a}$ & 953 a & $20.61 \mathrm{a}$ \\
\hline $\mathrm{S}_{4}=$ July 15 & 6.61 & 8.88 & 11.83 & $31.55 \mathrm{ab}$ & $4270 \mathrm{ab}$ & $771 \mathrm{ab}$ & $17.99 \mathrm{ab}$ \\
\hline $\mathrm{S}_{5}=$ July 25 & 5.66 & 8.42 & 11.55 & $25.16 \mathrm{~b}$ & $3576 \mathrm{bc}$ & $536 \mathrm{bc}$ & $15.06 \mathrm{bc}$ \\
\hline $\operatorname{LSD}(p=0.05)$ & NS & NS & NS & 7.70 & 1012 & 249 & 4.21 \\
\hline \multicolumn{8}{|l|}{ Interaction $S^{*} V$} \\
\hline $\mathrm{G}_{1} \times \mathrm{S}_{1}$ & $5.11 \mathrm{c}$ & 8.33 & $10.11 \mathrm{bc}$ & $28.56 \mathrm{bc}$ & 2847 e & $342 \mathrm{~d}$ & $12.02 \mathrm{~b}$ \\
\hline $\mathrm{G}_{1} \times \mathrm{S}_{2}$ & $6.11 b c$ & 9.00 & $10.00 \mathrm{c}$ & $28.89 \mathrm{bc}$ & $3766 \mathrm{~cd}$ & 381cd & $10.13 \mathrm{~b}$ \\
\hline $\mathrm{G}_{1} \times \mathrm{S}_{3}$ & $5.78 \mathrm{c}$ & 8.83 & $11.44 \mathrm{abc}$ & $29.00 \mathrm{bc}$ & $4028 \mathrm{~cd}$ & $729 \mathrm{bcd}$ & $18.09 \mathrm{ab}$ \\
\hline $\mathrm{G}_{1} \times \mathrm{S}_{4}$ & $5.56 \mathrm{c}$ & 9.67 & $11.67 \mathrm{ab}$ & $25.11 \mathrm{c}$ & $4375 \mathrm{bc}$ & $796 a b c$ & $18.18 \mathrm{ab}$ \\
\hline $\mathrm{G}_{1} \times \mathrm{S}_{5}$ & $6.00 \mathrm{bc}$ & 8.39 & $11.56 \mathrm{abc}$ & $24.56 c$ & $3472 \mathrm{de}$ & $475 \mathrm{~cd}$ & $13.68 \mathrm{ab}$ \\
\hline $\mathrm{G}_{2} \times \mathrm{S}_{1}$ & $6.11 b c$ & 8.89 & $10.22 \mathrm{bc}$ & $37.33 \mathrm{ab}$ & 3542 de & $534 c d$ & $15.08 \mathrm{ab}$ \\
\hline $\mathrm{G}_{2} \times \mathrm{S}_{2}$ & $6.00 \mathrm{bc}$ & 8.50 & $11.00 \mathrm{abc}$ & $36.22 \mathrm{ab}$ & $4997 \mathrm{ab}$ & $1061 \mathrm{ab}$ & $21.24 \mathrm{a}$ \\
\hline $\mathrm{G}_{2} \times \mathrm{S}_{3}$ & $7.89 a$ & 8.39 & $11.44 \mathrm{abc}$ & $42.56 \mathrm{a}$ & $5249 \mathrm{a}$ & $1179 \mathrm{a}$ & $22.46 \mathrm{a}$ \\
\hline $\mathrm{G}_{2} \times \mathrm{S}_{4}$ & $7.67 \mathrm{ab}$ & 8.11 & $12.00 \mathrm{a}$ & $38.00 \mathrm{ab}$ & $4167 \mathrm{~cd}$ & $748 \mathrm{bcd}$ & $17.95 \mathrm{ab}$ \\
\hline $\mathrm{G}_{2} \times \mathrm{S}_{5}$ & $5.33 c$ & 8.45 & $11.56 \mathrm{abc}$ & $25.78 c$ & $3681 \mathrm{~cd}$ & $597 \mathrm{~cd}$ & $16.23 \mathrm{ab}$ \\
\hline $\operatorname{LSD}(p=0.05)$ & 1.58 & NS & 1.67 & 9.60 & 820 & 358 & 8.24 \\
\hline
\end{tabular}

mungbean varieties and sowing dates were found for grain yield of mungbean. Greater grain yield (823 $\mathrm{kg} \mathrm{ha}^{-1}$ ) was obtained when NCM-13 was grown in the plots. While lesser grain yield $(544 \mathrm{~kg}$ $\mathrm{ha}^{-1}$ ) was produced by mungbean genotype NM11. Maximum grain yield $\left(953 \mathrm{~kg} \mathrm{ha} \mathrm{ha}^{-1}\right.$ ) was obtained for plots sown on July 5 and was found statistically at par for plots grown on July 15 and June 25 by producing grain yield (771 and $721 \mathrm{~kg} \mathrm{ha}^{-1}$ ) respectively. While minimum grain yield $(438 \mathrm{~kg}$ $\mathrm{ha}^{-1}$ ) was obtained in case of early sowing done on June 15 . In case of interaction, $\mathrm{G}_{2} \times \mathrm{S}_{3}$ recorded significantly maximum grain yield $\left(1179 \mathrm{~kg} \mathrm{ha}^{-1}\right)$. Due to regular availability of mild moisture throughout growing season specially at flowering and seed formation improved yield. Khan et al. (2001) reported that sowing date had significant effect on seed yield. The higher grain yield attributed to more number of pods plant ${ }^{-1}$ (Sadeghipour, 2008). Khan and Malik (2001) and Sarkar et al. (2004) also reported similar findings.

\section{Harvest index (\%)}

Similarly, higher harvest index (18.41\%) was recorded in NCM-13 genotype while it was recoded to be lower in NM-11 (14.55\%). In case of sowing dates harvest index was statistically maximum (20.61\%) when plots were sown on July 05 followed by $17.99 \%$ when the sowing was done on July 15. Minimum harvest index (12.98\%) was observed in case of early sowing, done on June 15 and the remaining sowing dates were found statistically at par. The interaction $\mathrm{G} \times \mathrm{S}$ was also found significant in which maximum harvest index $(22.46 \%)$ was observed for the interaction $\mathrm{G}_{2} \times \mathrm{S}_{3}$. These results are in confirmation with the findings of Saeed (1997) indicating that harvest index was significantly affected by mungbean genotypes. Similar results were also reported by Seijoon et al. (2000).

\section{Conclusions and Recommendations}

Mungbean genotypes vary for their yield potential and sowing date also influences greatly their yield per- 
formance. Among the genotypes NCM-13 was more promising. In case of planting times July 05 reported best outcomes followed by July 15 . So under rainfed conditions of the area mungbean genotype NCM13 may be recommended with 05-15 July sowing dates for maximizing the production. However further studies need to be continued for conformation of results in relation to changing climatic conditions of the area.

\section{Author's Contribution}

Muhammad Aqeel Sarwar conducted experiment and collected data. Shahid Riaz Malik conceived the idea and supervised the experiment. Waqas Ahmad and Muhammad Sajid Mahmood provided technical input at every step. Muhammad Jawad did statistical analysis. Muhammad Asadullah wrote abstract and introduction. Ijaz Ahmad and Muhammad Imran wrote the remaining article

\section{References}

Ahmad, M.S.A., M. Hossain, S. Ijaz and A.K. Alvi. 2008. Photosynthetic performance of two mungbean (Vigna radiata) cultivars under lead and copper stress. Int. J. Agric. Biol. 10: 167172.

Fraz, R.A., J. Iqbal, M. Bakhsh and M. Alias. 2006. Effect of sowing dates and planting patterns on growth and yield of mungbean (Vigna radiata L). Int. J. Agric. Biol. 8: 3.

Khan, A. and M.A. Malik. determining biological yield potential of different mungbean cultivars. Pak. J. Biol. Sci. 1 (7): 575-576.

Khan, S., S. Shah, H. Akbar and S. Khan. 2001. Effect of planting geometry on yield and yield components in mungbean. Sarhad J. Agric. 17: 519-24.

Lee, S.C., L.T. Gon, K.D. Chul, S.D. Seog, K.Y. Gook, S.C. Lee, T.G. Lim, D.C. Kim, D.S. Song and Y.G. Kim. 1997. Varietal differences in the major chemical components and the fatty acid composition of mungbeans. J. Crop. Sci. 42: 1-6

Miah, M.A.K., P. Anwar, M. Begum, A.S. Juraimi and M.A. Islam. 2009. Influence of sowing date on growth and yield of summer mungbean varieties. J. Agric. Soc. Sci. 5: 3.

Mondal, M.M.A. 2004. Performance of four summer mungbean varieties at Rangpur Zone of
Bangladesh. J. Nucl. Agric. 19: 145-149.

Patil, B.L., V.S. Hegde and P.M. Salimath. 2003. Studies on genetic divergence over stress and non-stress environment in mungbean. India. J. Genet. Plant Breed. 63: 77-78.

Poehlman, J.M., 1991. The Mungbean, 1st edition, pp: 27-29. Oxf. IBH Publ. Co. Pvt. Ltd., New Delhi, India.

Quresh, Z. and M. Rahim, 1987. Harvest index, grain yield and biological yield of soybean as affected by sowing dates and varieties. Pak. J. Agric. Res. 8: 387-93.

Rehman, A., S.K. Khalil, S. Nigar, S. Rehman, I. Haq, S. Akhtar, A.Z. Khan and S.R. Shah.2009. Phenology, Plant height and yield of mungbean varieties in response to planting date. Sarhad J. Agric. 25: 2.

Sadeghipour, O. 2008. Response of mungbean varieties to different sowing dates. Pak. J. Biol. Sci. 11 (16): 2048-2050. https://doi.org/10.3923/ pjbs.2008.2048.2050

Saeed, F. 1997. Response of spring and autumn sown Mungbean (Vigna radiata L.) genotypes to different dozes of nitrogen. M.Sc. Thesis, Department of Agronomy, Univ. Agric. Faisalabad.

Samanta, S.C., M.H. Rashid, P. Biswas and M.A. Hasan. 1999. Performance of five cultivars of mungbean under different dates of sowing. Bangladesh J. Agric. Res. 24: 521-527.

Sarkar, M.A.R., M.H. Kabir, M. Begum and M.A. Salam. 2004. Yield performance of mungbean as affected by planting date and planting density. J. Agron. 3: 18-24. https://doi.org/10.3923/ ja.2004.18.24

Seijoon, P., K. Wookhan and S. Rakehun. 2000. Influence of different planting times on harvest index and yield determination factors in soybean. Korean J. Crop Sci. 45: 97-102.

Sharar, M.S., M. Ayub, M.A. Nadeem and S.A. Noori. 2001. Effect of different row spacing and seeding densities on the growth and yield of gram (Cicer arietinum L.). Pak. J. Agric. Sci. 38: 51-53.

Siddique, M., M.F.A. Malik and S.I. Awan. 2006. Genetic divergence, association and performance evaluation of different genotypes of mungbean (Vigna radiata). Int. J. Agric. Biol. 8: 793-795.

Soomro, N.A. 2003. Response of mungbean genotypes to different dates of sowing in kharif 
season under rainfed condition. Asian J. Plant Sci. 2: 377-379. https://doi.org/10.3923/ ajps.2003.377.379

Steel, R., J. Torrie and D. Dickey. 1997. Principals and procedures of statistics. A biometrical approach. 3rd Eds. McGraw Hi fi Book Co. Inc., New York, USA. 13: 1409-1414.

Taleei, A.R., N.K. Bandeh and B. Gholamie. 1999. Effect of sowing date on grain yield, yield components and percentage of protein in green gram cultivars. Iran. J. Agric. Sci. 29: 751-758.

Thirtle, C., L. Lin and J. Piesse. 2003. The impact of research-led agricultural productivity growth on poverty reduction in Africa, Asia and Latin America.World Develop.3:1959-1976.https:// doi.org/10.1016/j.worlddev.2003.07.001

Tomar, S.S. and A.S. Tiwari. 1996. Response of green gram and blackgram genotypes to plant density. Gurat Agric. Univ. Res. J. 21: 88-92. 